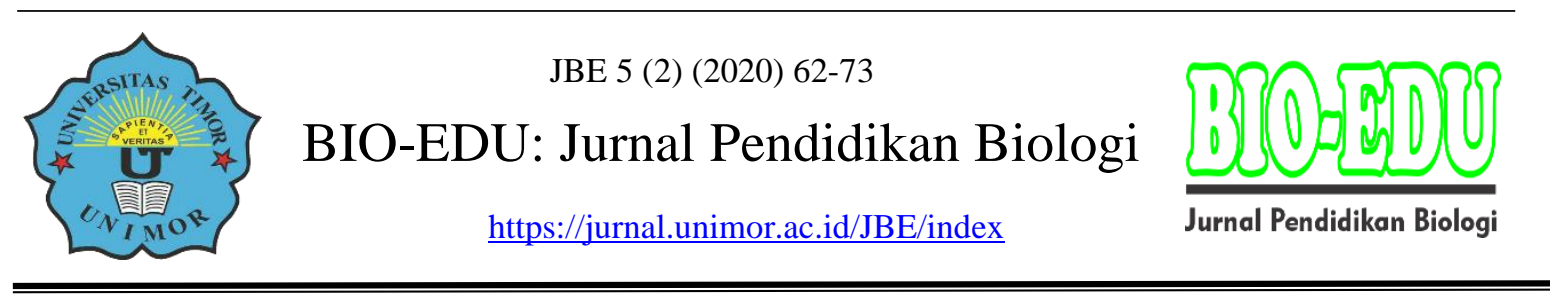

\title{
Pengembangan Modul Pembelajaran IPA Berbasis Etnosains Materi Interaksi Makhluk Hidup dengan Lingkungannya Untuk Menanamkan Jiwa Konservasi Siswa Kelas VII SMP
}

\author{
Niken Purnama Sari ${ }^{1}$, Suhirman $^{2}$, Ahmad Walid ${ }^{3}$ \\ Program Studi Ilmu Pengetahuan Alam, Jurusan Sains dan Sosial, \\ Fakultas Tarbiyah dan Tadris, Institut Agama Islam Negeri Bengkulu, Indonesia \\ E-mail: nikenpurnama.sari96@.gmail.com
}

DOI: https://doi.org/10.32938/jbe.v5i2.554

\begin{abstract}
Abstrak
Tujuan penelitian ini adalah untuk mengembangkan modul pembelajaran IPA berbasis etnosains yang memiliki kelayakan untuk dipakai setelah divalidasi. Metode penelitian menggunakan model pengembangan Borg \& Gall yang terdiri dari 6 tahap yaitu tahap studi pendahuluan, tahap merencanakan penelitian, tahap pengembangan desain, tahap uji lapangan terbatas, tahap revisi hasil uji tahap lapangan terbatas, dan tahap produk akhir. penelitian ini dibatasi pada tahap develop yaitu kelayakan modul. Instrument yang digunakan adalah angket untuk kelayakan modul. Subjek penelitian adalah 3 dosen Institut Agama Islam Negeri Bengkulu yang terdiri atas 1 dosen ahli bahasa, 1 dosen ahli materi, dan 1 dosen ahli media. Data hasil analisis angket dengan menghitung persentase pencapaian pada setiap komponen persentase pencapaian kriteria kelayakan modul pembelajaran IPA berbasis etnosains yang dikembangkan layak untuk digunakan dengan persentase $92,00 \%, 76,25 \%, 86,25 \%$ (kategori sangat layak, layak, dan sangat layak). Dari hasil data tersebut dapat disimpulkan bahwa modul telah layak digunakan sebagai bahan ajar dalam menunjang proses belajar mengajar pada materi interaksi makhluk hidup dengan lingkungannya di smp untuk kelas VII.
\end{abstract}

Kata Kunci: "interaksi makhluk hidup dengan lingkungannya; etnosains; modul; kelayakan”.

\begin{abstract}
The purpose of this study is to develop ethnics-based science learning modules that have the feasibility to be used after validation. The research method uses the Borg \& Gall development model which consists of 6 stages, namely a preliminary study stage, a research planning stage, a design development stage, a limited field test stage, a revised stage of the results of a limited field test stage, and a final product stage. This research is limited to the develop stage, namely the feasibility of the module. The instrument used was a questionnaire for module eligibility. The research subjects were 3 lecturers from Bengkulu State Islamic Institute which consisted of 1 language expert lecturer, 1 material expert lecturer, and 1 media expert lecturer. The results of the questionnaire analysis data by calculating the percentage of achievement in each component of the percentage of achievement of the eligibility criteria of the science learning module based on ethnoscience that was developed is suitable for use with a percentage of $92.00 \%, 76.25 \%, 86.25 \%$ (the category is very feasible, feasible, and very worthy). From the results of these data it can be concluded that the module is feasible to be used as teaching material in supporting the teaching and learning process on the material interaction of living things with their environment in junior high school for class VII.
\end{abstract}

Keywords:" interaction of living things with their environment; ethnics; modules; feasibility". 


\section{PENDAHULUAN}

Pendidikan adalah usaha sadar dan terencana untuk mewujudkan suasana belajar dan proses pembelajaran agar peserta didik secara aktif mengembangkan potensi dirinya untuk memiliki kekuatan spiritual keagamaan, pengendalian diri, kepribadian, kecerdasan, akhlak mulia, serta keterampilan yang diperlukan dirinya, masyarakat, bangsa, dan negara. Tujuan pendidikan adalah seperangkat hasil pendidikan yang tercapai oleh peserta didik setelah diselenggarakannya kegiatan pendidikan (Dirjen 2006).

Keberhasilan pendidikan berdasarkan kurikulum yang ada disekolah, kurikulum ialah sejumlah mata ajaran yang harus ditempuh dan dipelajari oleh siswa untuk memperoleh sejumlah pengetahuan. Kurikulum disusun untuk mewujudkan tujuan pendidikan nasional dengan memperhatikan tahap perkembangan peserta didik dan kesesuaiannya dengan lingkungan, kebutuhan pembangunan nasional, perkembangan ilmu pengetahuan dan teknologi serta kesenian, sesuai dengan jenis dan jenjang masingmasing satuan pendidikan (Oemar 2011).

Guru merupakan komponen penting dalam pendidikan, karena guru adalah suritauladan bagi siswa, segala bentuk tingkah lakunya akan diperhatikan oleh siswa. Bukan hanya pandai menyampaikan materi pembelajaran tetapi guru juga dituntut untuk menanamkan nilai-nilai karekter terhadap peserta didik, agar peserta didik mempunyai jiwa konservasi yang tinggi. Sebagaimana firman Allah SWT dalam Q.S. Al-Mujadalah: 11:

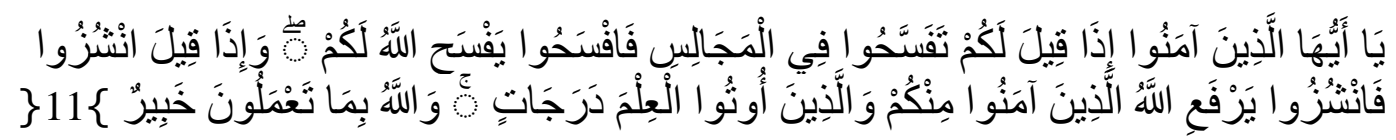

Artinya: Hai orang-orang beriman apabila kamu dikatakan kepadamu: "Berlapanglapanglah dalam majlis", Maka lapangkanlah niscaya Allah akan memberi kelapangan untukmu. dan apabila dikatakan: "Berdirilah kamu", Maka berdirilah, niscaya Allah akan meninggikan orang-orang yang beriman di antaramu dan orang-orang yang diberi ilmu pengetahuan beberapa derajat. dan Allah Maha mengetahui apa yang kamu kerjakan. (Q.S. Al-Mujadalah,58:11) (Abuddin 2014).

Dalam proses belajar mengajar guru sangat diperlukan untuk mengatasi kesulitan belajar peserta didik. Namun guru tidak dapat mengambil keputusan dalam membantu peserta didiknya yang mengalami kesulitan belajar jika guru tidak tahu di mana letak kesulitannya. Oleh karena itu seorang guru perlu mengetahui kesulitan peserta didik dalam belajar dan juga mengetahui penyebabnya. Landasan Qur'ani yang penulis pakai, sebagaimana firman Allah SWT dalam Q.S. Al-Insyiroh: 6:

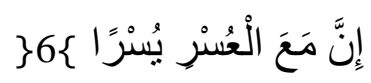

Artinya: Sesungguhnya sesudah kesulitan itu ada kemudahan. (Q.S. Al-Insyiroh, 94: 6) (Departemen Agama RI 2015).

Ayat di atas menerangkan bahwa manusia dapat memanfa'atkan potensi-potensi yang diberikan Allah kepada mereka untuk mengatasi berbagai kesulitan, sesungguhnya dalam kesulitan selalu disertai kemudahan tentunya dengan menggunakan akal serta usaha yang keras untuk mengatasi kesulitan tersebut.

Pada kurikulum 2013, KD mata pelajaran IPA sudah memadukan konsep dari aspek fisika, biologi, kimia serta bumi dan antariksa, tetapi tidak semua aspek tersebut 
dapat dipadukan karena pada suatu topik IPA tidak semua aspek dapat dipadukan satu sama lain. Proses pembelajarannya menekankan pada pemberian pengalaman langsung untuk mengembangkan kompetensi agar menjelajahi dan memahami alam sekitar secara ilmiah. Dan siswa dituntut untuk bisa belajar mandiri. Belajar mandiri adalah cara belajar aktif dan partisipatif untuk mengembangkan diri masing-masing individu yang tidak terikat dengan kahadiran guru, dosen, pertemuan tatap muka di kelas, dan kehadiran teman sekolah (Martinis 2007).

Pendidikan lebih menitikberatkan pada pembentukan dan pengembangan kepribadian, jadi mengandung pengertian yang lebih luas sedangkan latihan (training) lebih menekankan pembentukan keterampilan (skill) (Oemar 2011). Hal ini sesuai dengan pendidikan abad ke-21 yang mana menekankan siswa untuk memiliki skill. Pembelajaran adalah suatu kombinasi yang tersusun meliputi unsur-unsur manusiawi, material, fasilitas, perlengkapan, dan prosedur yang saling mempengaruhi mencapai tujuan pembelajaran.

Pada era transformasi pendidikan abad ke-21 merupakan arus perubahan dimana guru dan siswa akan sama-sama memainkan peranan penting dalam kegiatan pembelajaran. Peranan guru bukan hanya sebagai transfer of knowledge atau guru merupakan satu-satunya sumber belajar yang bisa melakukan apa saja (teacher center), melainkan guru sebagai mediator dan fasilitator aktif untuk mengembangkan potensi aktif siswa yang ada pada dirinya (Rusman 2017).

Tujuan pembelajaran akan tercapai apabila ditunjang dengan adanya komponenkomponen dalam proses tersebut. Salah satunya dengan adanya bahan ajar, misalnya modul. Modul merupakan sebuah bahan ajar cetak yang digunakan siswa untuk sumber belajar. Modul juga bertujuan untuk membuat siswa dapat belajar mandiri, dapat dipelajari kapan saja dan dimana saja tanpa harus ada alat pendukung. Modul juga berperan dalam melatih siswa untuk belajar aktif serta dapat pula menunjang keefektifan pencapaian tujuan pembelajaran. Modul yang akan dikembangkan juga dilengkapi dengan gambar-gambar yang menunjang untuk penanaman karakter konservasi bagi siswa (Sudarmin 2015).

Pendidikan yang relevan dengan upaya menghadapi tantangan zaman yaitu pendidikan yang mampu mengembangkan kompetisi dan membentuk watak yang relevan dengan upaya menghadapi tantangan zaman. Pendidikan dan pembelajaran harus bermakna sebagai proses pemberdayaan kemampuan berpikir kritis dan berpikir kreatif, kemampuan menyelesaikan masalah, kemampuan bekerja dengan etos kerja yang baik, kemampuan meneliti dan mengembangkan ilmu pengetahuan dan teknologi (IPTEK), dan membudayakan sikap mandiri, bertanggungjawab, demokratis, jujur, dan bermoral (Jufri 2017).

Mengingat tantangan pembelajaran di abad ke-21 maka penggunaan Modul sangat cocok jika digunakan dalam pembelajaran di SMP, karakteristik Modul bersifat sistematis, runut dan mampu menjadikan materi biologi yang rumit menjadi sederhana. Modul berbasis etnosains sangat cocok digunakan di SMP yang mana kegiatan pembelajarannya dengan pengenalan tentang sains asli dan sains ilmiah (Sudarmin 2015). Ketersediaan Modul yang didesain berdasarkan kebutuhan siswa diharapkan mampu menunjang aktivitas belajar siswa menjadi lebih baik, khususnya dalam mengembangkan ranah keterampilan proses. 


\section{Kajian penelitian terdahulu}

Beberapa penelitian yang relevan dengan penelitian ini adalah:

1. Penelitian yang dilakukan oleh Massita Rhoida Nailiyah pada tahun 2016 yang berjudul Pengembangan Modul IPA Tematik Berbasis Etnosains Kabupaten Jember Pada Tema Budidaya Tanaman Tembakau di SMP. Perbedaan penelitian ini dengan yang diteliti oleh peneliti terletak pada pendekatan etnosains yang digunakan, penelitian ini menggunakan pendekatan etnosains yaitu budidaya tanaman tembakau. Sedangkan penelitian yang dilakukan peneliti adalah pendekatan etnosains berdasarkan budaya adat yang dipercayai masyarakat.

2. Penelitian yang dilakukan oleh Wiwin Eka Rahayu pada tahun 2015 yang berjudul Pengembangan Modul IPA Terpadu Berbasis Etnosains Tema Energi Dalam Kehidupan Untuk Menanamkan Jiwa Konservasi Siswa. Perbedaan penelitian ini dengan yang diteliti oleh peneliti terletak pada tema yang digunakan.

3. Penelitian yang dilakukan oleh Nur Intan Fitriani pada tahun 2017 yang berjudul Efektivitas Modul IPA Berbasis Etnosains Terhadap Peningkatan Keterampilan Berpikir Kritis Siswa. Perbedaan penelitian ini dengan yang diteliti oleh peneliti terletak pada tujuan pembuatan modul, yakni modul yang dibuat oleh Nur Intan Fitriani hanya bertujuan untuk mendeskripsikan keefektifan modul ipa berbasis etnosains terhadap peningkatan keterampilan berpikir kritis siswa.

Berdasarkan hasil wawancara peneliti dengan beberapa guru Biologi di SMP, terdapat berbagai kendala yang dialami guru dalam proses pembelajaran, diantaranya penggunaan buku yang masih terpaku pada buku paket yang tebal yang disediakan oleh pihak sekolah, buku paket yang digunakan guru dalam pembelajaran adalah buku paket yang disediakan yang dibeli dari penerbit bukan hasil inovasi dari guru itu sendiri. Keadaan ini membuat proses pembelajaran menjadi tidak seimbang, karena cenderung mengabaikan ranah keterampilan dan afektif. Dengan adanya penelitian ini diharapkan agar siswa bisa memahami pembelajaran interaksi makhluk hidup dengan lingkungannya dengan mudah. Pendekatan etnosains yang digunakan bisa membuat siswa mengetahui adat/kebiasaan masyarakat setempat yang selama ini dipercayai, dan dengan siswa bisa memahami diharapkan budaya tersebut tidak akan hilang, dan akan terus menerus dilakukan.

Di berbagai SMP di Bengkulu masih belum ada bahan ajar berupa modul yang menarik dan berkarekter. Berdasarkan hasil wawancara dengan guru mata pelajaran IPA juga mengatakan bahwa disekolah belum menggunakan modul yang dikembangkan oleh guru sendiri seperti modul IPA berbasis etnosains yang mana kegiatan pembelajarannya dengan pengenalan tentang sains asli dan sains ilmiah.

Oleh sebab itu peneliti ingin mengembangkan suatu bahan ajar Modul yang berdasarkan pada kebutuhan peserta didik. Modul yang dapat menunjang proses pembelajaran adalah Modul yang sesuai dengan tujuan pencapaian pada suatu kompetensi dasar, serta dapat mencerminkan keterampilan proses sains siswa sesuai dengan pendekatan sainstifik, sehingga dalam pengembangannya Modul tersebut perlu disusun dengan mempertimbangkan penggunaan sumber belajar yang relevan. Maka dari itu peneliti tertarik untuk Mengembangkan Modul Pembelajaran IPA Berbasis Etnosains materi interaksi makhluk hidup dengan lingkungannya untuk menanamkan jiwa konservasi siswa kelas VII SMP. 


\section{METODE}

\section{Jenis dan Prosedur Penelitian}

Penelitian ini merupakan jenis penelitian pengembangan (research and development). Model pengembangan yang digunakan mengacu pada model pengembangan Borg \& Gall yang terdiri dari 6 tahap yaitu tahap studi pendahuluan, tahap merencanakan penelitian, tahap pengembangan desain, tahap uji lapangan terbatas, tahap revisi hasil uji tahap lapangan terbatas, dan tahap produk akhir.

\section{Studi Pendahuluan (Research and Information Collecting)}

Langkah studi pendahuluan(research and information collecting) ini meliputi analisis kebutuhan, studi pustaka, studi literatur, dan penelitian skala kecil yang di lakukan.

\section{Merencanakan Penelitian}

Setelah melakukan studi pendahuluan, langkah kedua yaitu merencanakan penelitian. Perencanaan penelitian R \& D meliputi : 1) merumuskan tujuan penelitian, 2) memperkirakan tenaga, dana, dan waktu, 3) merumuskan kualifikasi peneliti dan bentukbentuk dalam penelitian.

\section{Pengembangan Desain (Develop Preliminary Of Product)}

Yaitu mengembangkan untuk permulaan dari produk yang akan di hasilkan. Termasuk dalam langkah ini adalah persiapan komponen pendukung, mentiapkan buku pedoman dan petunjuk, dan melakukan evaluasi terhadap kelayakan produk. Langkah pengembangan desain ini meliputi : 1) menentukan desain produk yang akan dikembangkan, 2) menentukan sarana dan prasarana penelitian yang dibutuhkan selama proses penelitian dan pengembangan, 3) menentukan tahap- tahap pelaksanaan uji desain di lapangan. 4) menentukan pihak yang terlibat dalam penelitian.

\section{Uji lapangan terbatas (Preliminary Field Testing)}

Langkah ini merupakan model atau desain berdasarkan uji lapangan terbatas. penyempurnaan produk awal akan dilakukan setelah dilakukan uji coba lapangan terbatas.

\section{Revisi Hasil Uji lapangan terbatas (Main Product Revision)}

Yaitu melakukan perbaikan terhadap produk awal yang dihasilkan berdasarkan hasil uji coba awal. Perbaikan ini sangat mugkin dilakukan lebih dari satu kali, sesuai dengan hasil yang ditunjukkan dalam uji coba terbatas, sehingga di peroleh draf produk utama yang siap diuji coba lebih luas.

\section{Produk akhir}

Setelah dilakukan uji coba produk secara luas maka tahap akhir dari pembuatan modul ini yaitu produk akhir dan modul bisa digunakan untuk proses belajar siswa.

\section{Instrumen Penelitian}

Instrument yang digunakan dalam penelitian ini berupa angket kelayakan modul untuk mendapatkan data hasil validasi dari 3 validator. Angket validasi bahasa terdiri dari 15 komponen pernyataan dengan skor 1-5. Angket validasi materi terdiri dari 16 
komponen pernyataan dengan skor 1-5. Sedangkan Angket validasi media terdiri atas 16 komponen pernyataan dengan skor 1-5.

\section{Teknik Analisis Data}

Peneliti membuat lembar validasi yang berisikan pernyataan. Kemudian validator mengisi angket dengan memberikan tanda centang pada kategori yang telah disediakan oleh peneliti berdasarkan skala likert yang terdiri dari 5 skor penilaian sebagai berikut:

Table 1. Skor Penilaian Validasi Ahli

\begin{tabular}{lc}
\hline \multicolumn{1}{c}{ Keterangan } & Skor \\
\hline Sangat Baik (SB) & 5 \\
Baik (B) & 4 \\
Cukup (C) & 3 \\
Kurang (K) & 2 \\
Sangat Kurang (SK) & 1 \\
\hline
\end{tabular}

(Sumber: Qoriah, 2017)

Hasil validasi yang sudah tertera dalam lembar validasi modul akan dianalisis menggunkan rumus sebagai berikut:

$$
\mathrm{P}=\frac{f}{N} \mathrm{X} 100 \%
$$

Keterangan:

$\mathrm{P}=$ angka persentase data angket

$\mathrm{f}=$ jumlah skor yang diperoleh

$\mathrm{N}=$ jumlah skor maksimum

Selanjutnya persentase kelayakan yang didapatkan kemudian di interpretasikan ke dalam kategoti berdasarkan Tabel berikut:

Tabel 2. Kreteria Kelayakan

\begin{tabular}{cl}
\hline Penilaian & $\begin{array}{c}\text { Kreteria } \\
\text { Interpretasi }\end{array}$ \\
\hline $81 \leq \mathrm{P} \leq 100 \%$ & Sangat Layak \\
$61 \leq \mathrm{P}<81 \%$ & Layak \\
$41 \leq \mathrm{P}<61 \%$ & Cukup \\
$21 \leq \mathrm{P}<41 \%$ & Tidak Layak \\
$0 \leq \mathrm{P}<21 \%$ & Sangat Tidak \\
& Layak \\
\hline
\end{tabular}

Bahan ajar berbentuk modul dinyatakan layak secara teoritis apabila persentase kelayakan adalah $\geq 51 \%$.

\section{HASIL DAN PEMBAHASAN}

Untuk melihat kelayakan modul, telah dilakukan validasi modul pada 3 dosen Institut Agama Islam Negeri Bengkulu. 1 dosen validasi bahasa, 1 dosen validasi materi, dan 1 dosen validasi media.

Sebelum menghitung persentase skor penilaian validasi ahli, akan dihitung terlebih dahulu kelayakan sesuai dengan rumus tabel 1 . 
Tabel 3. Data Hasil Validasi Ahli Bahasa

\begin{tabular}{clcc}
\hline No & \multicolumn{1}{c}{ Komponen } & Skor & Kriteria \\
\hline 1 & Sesuai dengan perkembangan & 9 & Sangat layak \\
& siswa & & \\
2 & Komunikatif & 8 & Sangat layak \\
3 & Dialogis dan interaktif & 10 & $\begin{array}{c}\text { Sangat layak } \\
\text { Sangat layak }\end{array}$ \\
4 & Lugas & 8 & Sangat layak \\
5 & $\begin{array}{l}\text { Koherensi dan keruntutan alur } \\
\text { pikir }\end{array}$ & 10 & Sangat layak \\
6 & $\begin{array}{l}\text { Kesesuaian dengan kaidah } \\
\text { bahasa Indonesia yang baik } \\
\text { dan benar }\end{array}$ & 10 & \\
$7 \quad \begin{array}{l}\text { Penggunaan istilah dan } \\
\text { simbol/lambang }\end{array}$ & 14 & Sangat layak \\
\hline Jumlah total & & 69 \\
\hline Skor maksimal & & 75 \\
\hline Persentase & & Sangat layak \\
\hline Kriteria & & \\
\hline
\end{tabular}

Keterangan:

Validator ahli bahasa: Vebbi Andra, M.Pd

Berdasarkan hasil pengembangan yang telah dilakukan, diketahui hasil dari validator terhadap Modul pembelajaran IPA berbasis Etnosains diperoleh hasil 92,00\%. Sehingga dari hasil validator tersebut mengacu pada tabel konversi, maka dapat ditarik kesimpulan bahwa Modul pembelajaran IPA berbasis Etnosains yang dikembangkan sudah layak digunakan atau sudah dapat diuji cobakan kepada siswa dalam proses pembelajaran dan tidak perlu lagi direvisi oleh peneliti. Adapun saran dan komentar validator terhadap pengembangan Modul pembelajaran IPA berbasis Etnosains sebagai berikut:

Tabel 4. Saran dan Masukan Ahli Bahasa Sebelum dan Setelah Direvisi

\begin{tabular}{|c|c|c|}
\hline Validator & Saran dan Komentar & Keterangan \\
\hline Ahli Bahasa & $\begin{array}{l}\text { 1. Setiap gambar sebaiknya } \\
\text { cantumkan sumber } \\
\text { 2. Tanda titik sesudah } \\
\text { kalimat harus konsisten } \\
\text { 3. Nama tempat/daerah } \\
\text { diawali dengan huruf } \\
\text { kafital }\end{array}$ & $\begin{array}{l}\text { Produk siap digunakan } \\
\text { dalam kegiatan pembelajaran }\end{array}$ \\
\hline
\end{tabular}

Tabel 5. Data Hasil Validasi Ahli Materi

\begin{tabular}{clcl}
\hline No & \multicolumn{1}{c}{ Komponen } & Skor & Kriteria \\
\hline 1 & Materi & 14 & Sangat layak \\
2 & Kemutakhiran & 12 & Sangat layak \\
3 & Merangsang keingintahuan melalui & 12 & Sangat layak
\end{tabular}

pendekatan Etnosains 


\begin{tabular}{llcc}
4 & Mengembangkan kecakapan hidup & 12 & Sangat layak \\
5 & Mengembangkan wawasan & 7 & Layak \\
& kebhinekaan & & Sangat layak \\
$6 \quad$ Mengandung wawasan kontekstual & 4 & 61 \\
\hline Jumlah total & & 80 \\
\hline Skor maksimal & & $76,25 \%$ \\
\hline Persentase & Layak \\
\hline Kriteria
\end{tabular}

Keterangan :

Validator ahli materi : Naintyn Novitasari, M.Pd

Berdasarkan hasil pengembangan yang telah dilakukan, diketahui hasil dari validator terhadap modul pembelajaran IPA berbasis Etnosains diperoleh hasil 76,25\%. Sehingga dari hasil validator tersebut mengacu pada tabel konversi, maka dapat ditarik kesimpulan bahwa modul pembelajaran IPA berbasis Etnosains yang dikembangkan sudah layak digunakan atau sudah dapat diuji cobakan kepada siswa dalam proses pembelajaran dan tidak perlu lagi direvisi oleh peneliti. Adapun saran dan komentar validator terhadap pengembangan modul pembelajaran IPA berbasis Etnosains sebagai berikut:

Tabel 6. Saran dan Masukan Ahli Materi Sebelum dan Setelah Direvisi

\begin{tabular}{ccc}
\hline Validator & \multicolumn{1}{c}{ Saran dan Komentar } & \multicolumn{1}{c}{ Keterangan } \\
\hline Ahli Materi & $\begin{array}{l}\text { 1. Tambahkan referensi untuk } \\
\text { memperbanyak isi pada } \\
\text { materi yang diangkat. }\end{array}$ & $\begin{array}{l}\text { Produk siap digunakan dalam } \\
\text { 2. Perhatikan huruf kembelajaran } \\
\text { miring, spasi, dll }\end{array}$ \\
\hline
\end{tabular}

\section{Tabel 7. Data Hasil Validasi Ahli Media}

\begin{tabular}{llcc}
\hline No & \multicolumn{1}{c}{ Komponen } & Skor & Kriteria \\
\hline 1 & Tampilan tulisan & 20 & Sangat layak \\
2 & Tampilan gambar & 16 & Sangat layak \\
3 & Fungsi modul & 16 & Sangat layak \\
$4 \quad$ Manfaat modul & 17 & Sangat layak \\
\hline Jumlah total & & 69 \\
\hline Skor maksimal & & 80 \\
\hline Persentase & & $86,25 \%$ \\
\hline Kriteria & & Sangat Layak \\
\hline
\end{tabular}

Keterangan :

Validator ahli desain : Raden Gamal Tamrin Kusumah, M.Pd

Jumlah persentase hasil validasi yang dilakukan validator ahli media terhadap pengembangan modul pembelajaran pembelajaran IPA berbasis Etnosains adalah 86,25 $\%$ yang terdiri atas 16 indikator. Sehingga dari hasil validasi tersebut mengacu pada tabel konversi, maka dapat ditarik kesimpulan bahwa modul pembelajaran IPA berbasis Etnosains yang dikembangkan sudah layak digunakan atau sudah dapat diuji cobakan kepada siswa dalam proses pembelajaran dan tidak perlu lagi direvisi oleh peneliti. 
Adapun saran dan komentar validator terhadap pengembangan modul pembelajaran IPA berbasis Etnosains sebagai berikut:

Tabel 8. Saran dan Masukan Ahli Media Sebelum dan Setelah Direvisi

\begin{tabular}{clc}
\hline Validator & Saran dan Komentar & \multicolumn{1}{c}{ Keterangan } \\
\hline Ahli Media & $\begin{array}{l}\text { Sediakan lembar isian } \\
\text { untuk siswa }\end{array}$ & $\begin{array}{l}\text { Produk siap digunakan } \\
\text { dalam kegiatan pembelajaran }\end{array}$
\end{tabular}

Tabel 9. Hasil Scan Modul Pembelajaran IPA Berbasis Etnosains

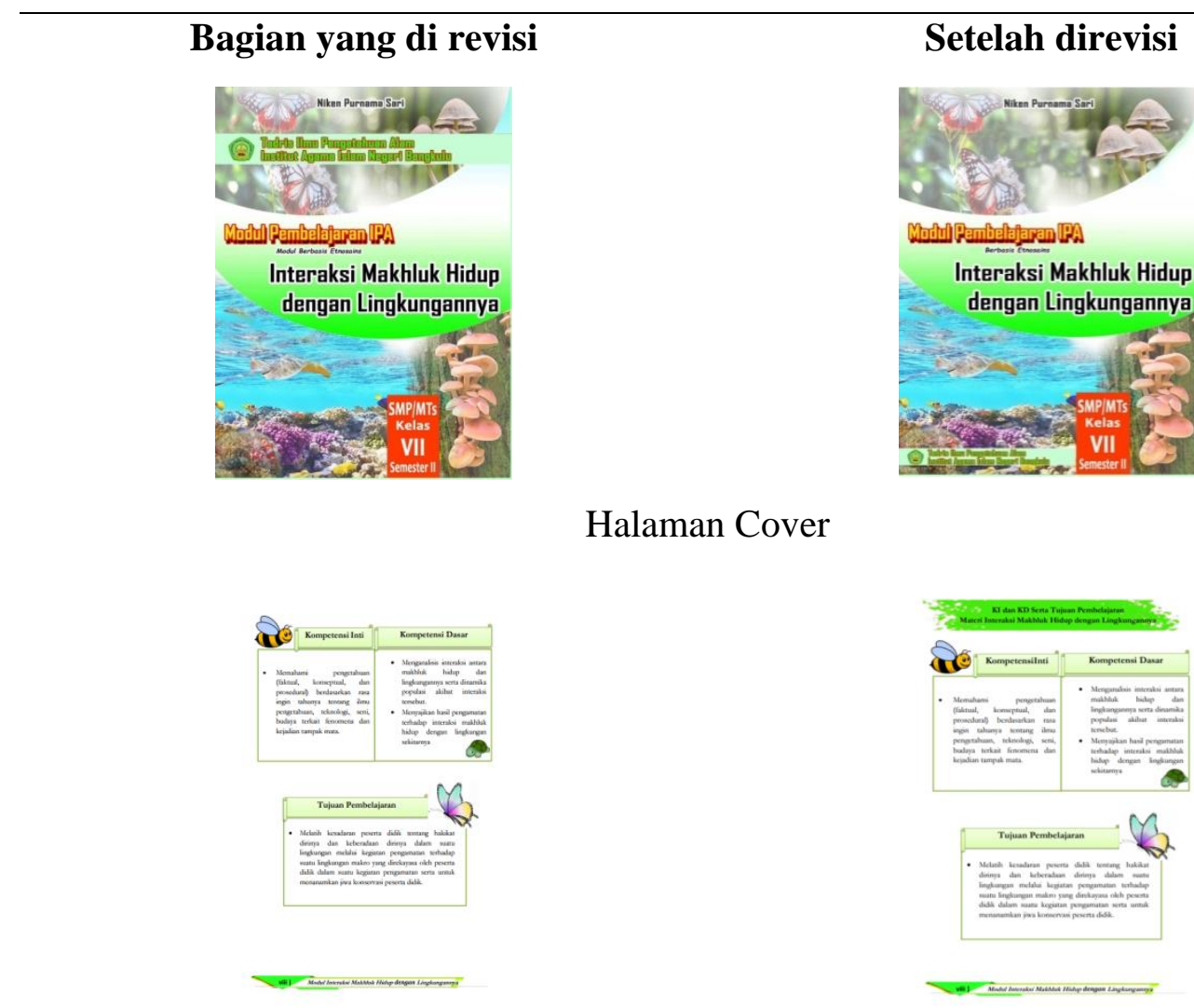

KI, KD dan tujuan pembelajaran
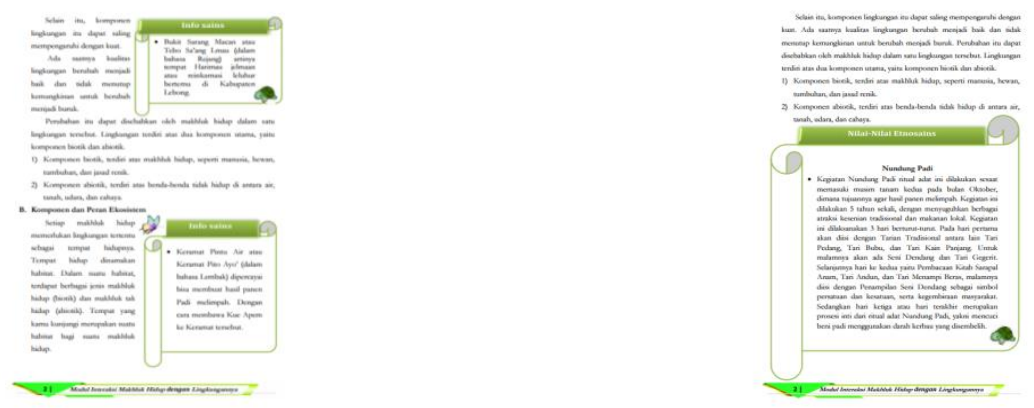

Nilai-nilai etnosains 
Berdasarkan hasil data table 3, 5, dan 7 terlihat bahwa persentase pencapaian kriteria kelayakan untuk setiap komponen sudah berada pada kriteria sangat layak. Dari hasil validasi yang diperoleh dapat disimpulkan bahwa modul telah praktis untuk digunakan sebagai bahan ajar.

Tiga dosen validator memberikan komentar positif yaitu modul sangat bagus untuk digunakan sebagai bahan ajar. Sementara itu berdasarkan saran yang diperoleh dari validator, ada beberapa revisi yang dilakukan yaitu memperbaiki tanda baca, menambahkan halaman francis, menambahkan sumber gambar pada modul, dan menambahkan isian siswa/peserta didik pada modul.

Setelah direvisi oleh peneliti maka hasil yang didapatakan adalah Modul Pembelajaran IPA Berbasis Etnosains Materi Interaksi Makhluk Hidup dengan Lingkungannya Untuk Menanamkan Jiwa Konservasi Siswa Kelas VII SMP dinyatakan sangat layak digunakan dengan persentase $92,00 \%$ (bahasa), 76,25\% (materi), dan $86,25 \%$ (media).

\section{KESIMPULAN DAN SARAN}

\section{Kesimpualan}

Berdasarkan hasil validasi dari 3 dosen Institut Agama Islam Negeri Bengkulu yaitu ahli bahasa, ahli materi, dan ahli media maka Modul Pembelajaran IPA Berbasis Etnosains Materi Interaksi Makhluk Hidup dengan Lingkungannya Untuk Menanamkan Jiwa Konservasi Siswa Kelas VII SMP yang dikembangkan setelah melakukan revisi dinyatakan sangat layak untuk digunakan dengan persentase $92,00 \%, 76,25 \%, 86,25 \%$ (kategori sangat layak, layak, dan sangat layak ).

\section{Saran}

Berdasarkan hasil perolehan penelitian, maka penelitian dapat menyampaikan beberapa saran sebagai berikut:

1. Bagi siswa penelitian ini di harapkan sebagai salah satu sumber belajar berupa modul yang menggunakan pendekatan etnosains .

2. Bagi guru penelitian ini di harapkan dapat di jadikan acuan selanjutnya untuk lebih menekan pada pembelajaran berbasis etnosains.

3. Bagi peneliti lain dapat mencoba mengembangkan bahan ajar serupa pada materi yang berbeda sesuai kebutuhan.

4. Bagi peneliti agar membuat modul lanjutan untuk seluruh materi yang ada dikelas VII untuk SMP yang belum ada tercakup dalam modul.

\section{DAFTAR PUSTAKA}

Arlitasari, Oni, \& Pujayanto, Rini Budiharti,. (2013). Pengembangan Bahan Ajar IPA Terpadu Berbasis Salingtemas dengan tema Biomassa Sumber Energi Alternatif Terbarukan. Jurnal Pendidikan Fisika, 1 (1): 81-89

Arum, Tia Sekar dan Wahyudi. (2016). Pengembangan Modul Pembelajaran Tematik Integratif Subtema Hubungan Makhluk Hidup Dalam Ekosistem Pendekatan Saintifik untuk Kelas 5 SD. Scholaria, 6 (3),) hal. 240

Battiste, M. (2005). Indegenous Knowledge: Foundation For First Nations. Canada: University Of Saskatchewan. 
Direktorat Jenderal Pendidikan Islam Departement Agama RI, (2006). Undang-undang dan Peraturan Pemerintah RI.

Departemen Agama RI. (2009). Al-Qur'an dan Terjemahannya.

Fatikhah, Ismu. (2015). Pengembangan Modul Pembelajaran Matematika Bermuatan Emotion Quotient pada Pokok Bahasan Himpunan. Jurnal Tadris Matematika, IAIN Syekh Nurjati Cirebon, 4 (4): 207-219

Hamalik, Oemar. (2011). Kurikulum dan Pembelajaran. Jakarta: Bumi Aksara

Jufri, Wahab.A,. (2017). Belajar dan Pembelajaran Sains. Bandung: Pustaka Reka Cipta

Kusumah R. G. T.,Walid, A., Pitaloka, S., Dewi, P.S., \&Agustriana, N. (2020). Penerapan Model Inquiry Sebagai Usaha Untuk Meningkatkan Hasil Belajaripa Pada Materi Penggolongan Hewan di Kelas IV Sd Seluma. Jurnal Pendidikan Matematika dan IPA, 11 (1). 142-153

MA, Abuddin Nata. (2014). Tafsir Ayat-Ayat Pendidikan. Jakarta: PT Raja Grafindo Persada

Massita, et al., (2016). Pengembangan Modul IPA Tematik Berbasis Etnosains Kabupaten Jember Pada Tema Budidaya Tanaman Tembakau di SMP, Jurnal pembelajaran fisika, 5 (3): 261-269

Purwanto, Budi. (2017). Ilmu Alam untuk kelas VII SMP dan MTs. Solo: PT Tiga Serangkai Pustaka Mandiri

Qoriah, Y., Sumarno dan Umamah, N.,( 2017). The Development Prehistoric Of jember Tourism Module Using Dick and Carey Model, Jurnal Historica, Vol. I, , Issue. 1

Rusman. (2017). Belajar dan Pembelajaran. Jakarta: Kencana

Sanjaya, Wina. (2013). Penelitian Pendidikan. Jakarta: Kencana

Setyosari, Punaji. (2013). Metode Penelitian Pendidikan dan Pengembangan. Jakarta: Kencana

Sudarmin. (2015). Pengembangan Modul IPA Terpadu Berbasis Etnosains Tema Energi Dalam Kehidupan Untuk Menanamkan Jiwa Konservasi Siswa”. Unnes science education journal, 4 (2): 919-926

Sugiyono. (2017). Metode Penelitian dan Pengembangan Research And Development. Bandung: Alfabeta

Walid, A., Sajidan., \& Ramli, m Constructing A Test For Assesing Higher Order Thinking Skills Of Hight School Student On Reprocdoctive System. In Proceeding Biology Education Conference: Biology, Science, Environment, And Learning, (Vol. 12, No 1, pp. 371-377)

Widodo, Wahono, Fida Rachmadiarti, dan Siti Nurul Hidayah. (2017). Ilmu Pengetahuan Alam. Jakarta: Kementerian Pendidikan dan Kebudayaan

Wisudawati, Asih Widi dan Eka Sulistyawati. (2014). Metodologi Pembelajaran IPA. Jakarta: Bumi Aksara

Yamin, Martinis. (2007). Desains Pembelajaran Berbasis Tingkat Satuan Pendidikan. Jakarta: Putra Grafika 
Yukaliana, et, al,.(2017). IPA Biologi. Jakarta: Erlangga

Yuliana, Ivo. (2017). Pembelajaran Berbasis Etnosains Dalam Mewujudkan Pendidikan Karakter Siswa Sekolah Dasar. Jurnal Pendidikan dan Pembelajaran Sekolah Dasar, 1 (2): 98-106

Zubaedi. (2011). Desain Pendidikan Karakter. Jakarta: Kencana 